Original Article

\title{
Homeopathic treatment of vitiligo: an open observational pilot study
}

\author{
Subhasish Ganguly¹, Subhranil Saha², Munmun Koley², Ramkumar Mondal ${ }^{1}$ \\ ${ }^{1}$ Mahesh Bhattacharyya Homoeopathic Medical College \& Hospital, West Bengal, India \\ 2 Clinical Research Unit (Homoeopathy), Siliguri, CCRH, Govt. of India
}

\begin{abstract}
Background: Vitiligo is a common hypopigmentation disorder with significant psychological impact. An evaluation of homeopathic treatment was performed in individuals with vitiligo in a hospital outpatient clinic in West Bengal, India. Methods: Thirty participants (median age 27 years old, 57\% female) were recruited for a prospective open-label pilot study and treated with individualized homeopathic medicines for 6 months. Efficacy was assessed after 3 months and 6 months using Vitiligo Area Scoring Index (VASI) score, Vitiligo European Task Force (VETF) score, and Dermatological Life Quality Index (DLQI) score, which are validated outcome measures evaluating the area, intensity, spread of depigmentation of vitiligo lesions, and quality of life (QoL). Results: A total of 27 participants completed the trial; 3 dropped out. After 6 months of treatment, the median VASI total score improved significantly by 0.1 units $(p=0.003)$, from $0.8(0.5,1.5)$ to $0.7(0.3,0.8)$ on a scale from 0 (no depigmentation) to 100 (completely depigmented). Similarly, the VETF median score improved by 2 units $(p=0.0001)$ from $1(0,1)$ to $1(-1,0)$ and the staging score changed from $1(1,2)$ to $1(0,1), p=0.002$. The total DLQI median score exhibited significant reduction from $21(17,22)$ to $13.6(10,17)$, change $7.4(p=0.0001)$, as also did its components. Conclusions: Individualized homeopathic treatment associated with significant improvement of VASI, VETF and DLQI scores. The extent to which the observed effects were due to placebo needs clarification in future randomized double-blind clinical studies preceded by feasibility studies.
\end{abstract}

Keywords: homoeopathy, vitiligo

\section{Introduction}

Vitiligo is the most common chronic depigmentation disorder, where the loss of functioning melanocytes causes the appearance of white patches on skin. Vitiligo affects $1 \%$ of the world population [1], but the prevalence is reported to be as high as $4 \%$ in some South Asian, Mexican and American populations [2-6]. In $50 \%$ of the cases, the disease appears before age 20 years old [7-10]; disfigurement might result in psychiatric disorders in 16 to $35 \%$ of patients [11], including low self-esteem, poor body image, depression, sleep disturbances, suicidal thoughts, suicidal attempts, difficulties in sexual relationships, and avoidance of social situations [11-16]. Vitiligo might be confused with leprosy, leading to further stigmatization [17]. It is cosmetically and psychologically devastating [18]. The pathogenesis of disease has not yet been fully elucidated [18-21] and treatment is often unsatisfactory [22]. Sixty-eight therapies have been evaluated in clinical trials over the last 43 years [1,23]. Several systematic reviews [6,18,19,24-29] assessed the clinical efficacy of topical corticosteroids, narrowband ultraviolet light B (UVB), psoralen with ultraviolet light A exposure (PUVA), calcipotriol, l-phenylalanine, topical immunomodulators (tacrolimus and pimecrolimus), excimer laser, surgical therapy, and natural health products (NHPs) in the management of vitiligo. These 
reviews concluded that these therapies are promising, however, concerns were raised about their long-term side effects, and thus further evaluation is needed before firm conclusions might be drawn. Due to the small numbers of participants and heterogeneity of the trials designs to date, it is difficult to make firm recommendations for clinical practice [1].

In spite of extensive searches in different databases [e.g. MEDLINE (via PubMed), Cochrane, Google Scholar, EMBASE (Elsevier), AMED (British Library), CCRH (India), CINAHL (EBSCO Publishing, Ovid Technologies, ProQuest), CISCOM (RCCM, London), CAM (University of Maryland, School of Medicine), HomInform (Glasgow Homeopathic Hospital), LILACS (Virtual Health Library, Brazil), MANTIS (ChiroAccess), and SIGLE (Europe)] using various search terms, only 4 observational studies on homeopathy on vitiligo could be identified [30-33]. The methodological quality of those studies is poor, and suffered from inadequate reporting, and lack of validated outcome measures. Therefore, the authors undertook the present observational study with validated outcome measures to evaluate the efficacy of individualized homeopathic treatment in patients with vitiligo.

\section{Methods}

In the present prospective observational study, patients were included consecutively upon their first consultation with a physician, and subsequently followed up using standardized questionnaires. The study protocol was approved by the institutional ethics committee of Mahesh Bhattacharyya Homeopathic Medical College and Hospital, Government of West Bengal, India. The assessed volunteers were 5 to 80 years old, from both sexes, and exhibited 25-75\%, residual depigmentation on VASI ; VETF stages 1 or 2, spread (+1) to $(-1)$. The volunteers already undergoing regular oral and/or topical conventional therapy or any other treatment for vitiligo were also included, provided treatments were fully stopped at least 1 month prior registering for the study. The volunteers using life-saving conventional drug therapies, e.g. anti-diabetics, antihypertensive drugs, thyroid drugs, etc., and stable were also included. Volunteers with uncontrolled, unevaluated or complicated systemic diseases or infections affecting the quality of life were excluded, as also were pregnant and nursing women.

At baseline, the volunteers' complaints were graded as per the VASI and VETF scores, while they were asked to rate their health-related QoL on DLQI. The same outcome measures and questionnaire were used after 3 months and 6 months to ensure a continuous assessment.

Statistical analysis followed the intention-to-treat approach, i.e. all the included volunteers entered the final analysis. We replaced the missing values by means of the maximum likelihood method. Analyses were performed using a laptop with Intel ${ }^{\circledR}$ Core $^{\mathrm{TM}}$ i3-2328M $2.20 \mathrm{GHz}$ processor, 2.00 GB RAM running Windows 7 64 bit and Microsoft Office Excel 2007, and various statistical computational websites. Non-parametric Friedman's test was applied to compare the data obtained longitudinally at baseline, after 3 months and 6 months. $p<0.05$ (two-tailed) was considered to be statistically significant.

Trial Registration: Clinical Trials Registry, India registration number CTRI/2013/08/003879.

\section{Results}

Out of 53 vitiligo patients screened at the outpatient department, 23 (43.4\%) were excluded, and 30 (56.6\%) were recruited. All of the enrolled patients were allocated to individualized homeopathic treatment. Three (10\%) volunteers dropped out; $27(90 \%)$ completed the study. All the recruited volunteers (n=30; 100\%) entered the final analysis. (Figure 1) 
Figure 1: Patient flow diagram (CONSORT/ReDHoT)

Screening of vitiligo patients at outpatient department as per eligibility criteria $(n=53)$

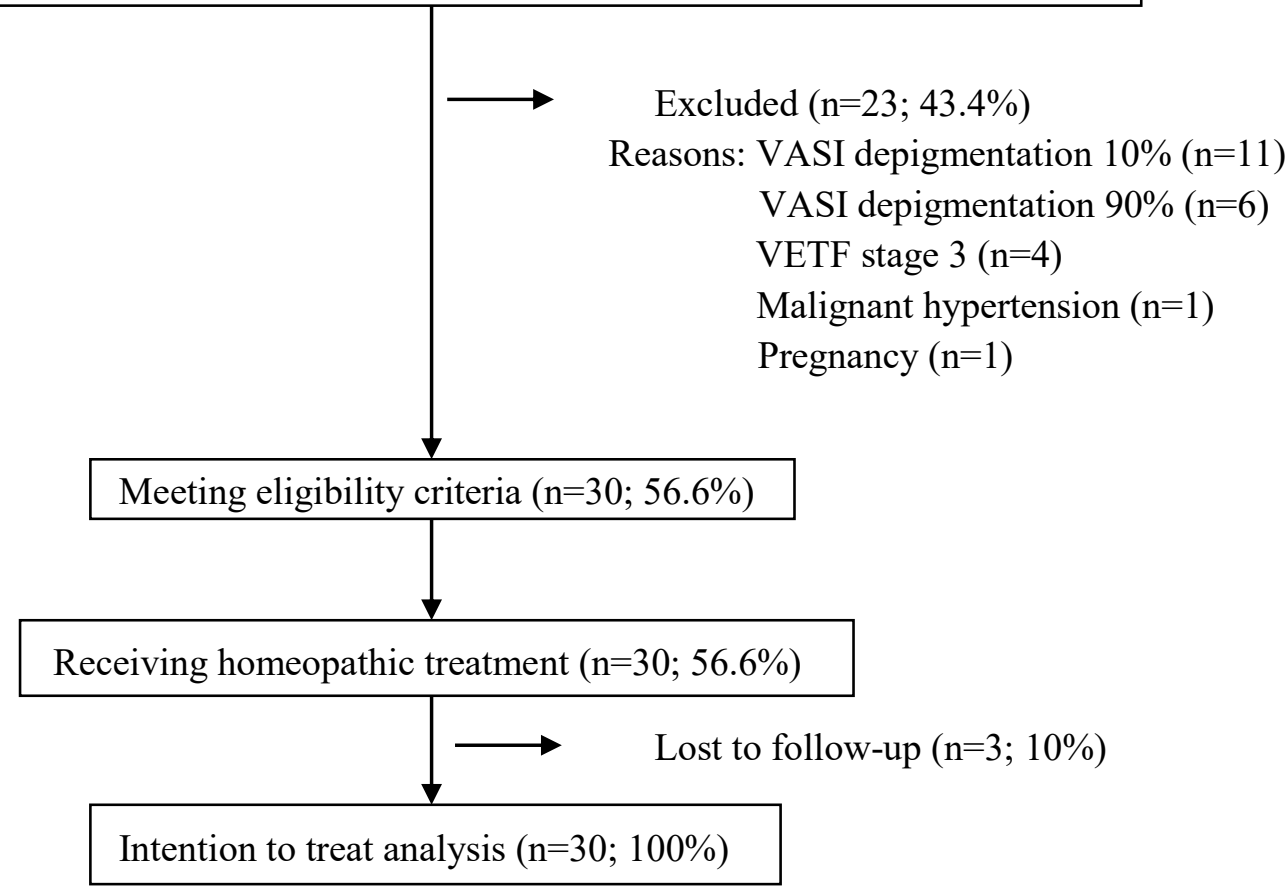

In the present analysis, we included 30 patients (Table 1) suffering from vitiligo for 18 months (median value; interquartile range - IQR 4 to 36). The median age of the sample was 27 years old (IQR 13 to 38), mostly belonging to the age group of $21-40$ years $(n=13 ; 43.3 \%)$, and mostly female $(n=17 ; 56.7 \%)$. Most participants were residents of urban areas $(n=21 ; 70 \%)$ and belonged to medium-income families $(n=24 ; 80 \%)$. Six $(20 \%)$ volunteers had a family history of vitiligo, and history of past injury on the vitiligo lesion sites. Out of 30 patients, $19(63.3 \%)$ had been previously treated for vitiligo, chiefly by means conventional therapy $(\mathrm{n}=15$; 79\%). Almost all accompanying diagnoses assessed at baseline were chronic diseases, especially anemia $(\mathrm{n}=14 ; 46.7 \%)$. (Table 1)

Table 1: Socio-demographic status of study sample

\begin{tabular}{|c|c|}
\hline Age in years; n (\%) & $27(13-38) \dagger$ \\
\hline $0-20$ & $11(36.7 \%)$ \\
\hline $21-40$ & $13(43.3 \%)$ \\
\hline $41-60$ & $4(13.3 \%)$ \\
\hline $61-80$ & $2(6.7 \%)$ \\
\hline \multicolumn{2}{|l|}{ Gender; n (\%) } \\
\hline Male & $13(43.3 \%)$ \\
\hline Female & $17(56.7 \%)$ \\
\hline \multicolumn{2}{|c|}{ Income status: Rupees/month; n (\%) } \\
\hline$<10,000$ & $6(20 \%)$ \\
\hline $10,000-20,000$ & $24(80 \%)$ \\
\hline \multicolumn{2}{|l|}{ Habitat; n (\%) } \\
\hline Urban & $21(70 \%)$ \\
\hline Rural & $9(30 \%)$ \\
\hline
\end{tabular}




\begin{tabular}{lr}
\hline Religion; n (\%) & \\
Hindu & $27(90 \%)$ \\
Islam & $3(10 \%)$ \\
\hline Positive family history of vitiligo; n (\%) & $6(20 \%)$ \\
\hline Positive history of injury & $6(20 \%)$ \\
\hline Previously treated for vitiligo; n (\%) & $19(63.3 \%)$ \\
Conventional medication & $15(79 \%)$ \\
Homeopathy & $2(10.5 \%)$ \\
Both & $2(10.5 \%)$ \\
\hline Baseline diagnoses other than vitiligo; & \\
n (\%) & $14(46.7 \%)$ \\
Anemia & $6(20 \%)$ \\
Frequent respiratory tract infections & $2(6.7 \%)$ \\
Migraine & $2(6.7 \%)$ \\
Warts & $5(16.7 \%)$ \\
Miscellaneous* & \\
\hline median (inter-quartile range) & \\
&
\end{tabular}

Upon their initial visit, the volunteers were subjected to a through medical consultation, followed by case analysis. All the volunteers were given the first homeopathic medication on that day. The subsequent visits were comparatively shorter. The total number of visits was 160, medicines were prescribed in 83 consultations (51.9\%), while the rest were placebo (77, 48.1\%). The dilution most frequently used was $200 \mathrm{cH}$, $78.3 \%$, followed by $1,000 \mathrm{cH}, 20.5 \%$. The homeopathic medicines most frequently prescribed were Sulphur (18.1\%), Thuja occidentalis (14.5\%), Calcarea carbonica (13.3\%), Natrum muriaticum (8.4\%), Nitricum acidum, and Pulsatilla nigricans (7.2\%). Change of remedies was indicated in 6 (20\%) cases. (Figure 2)

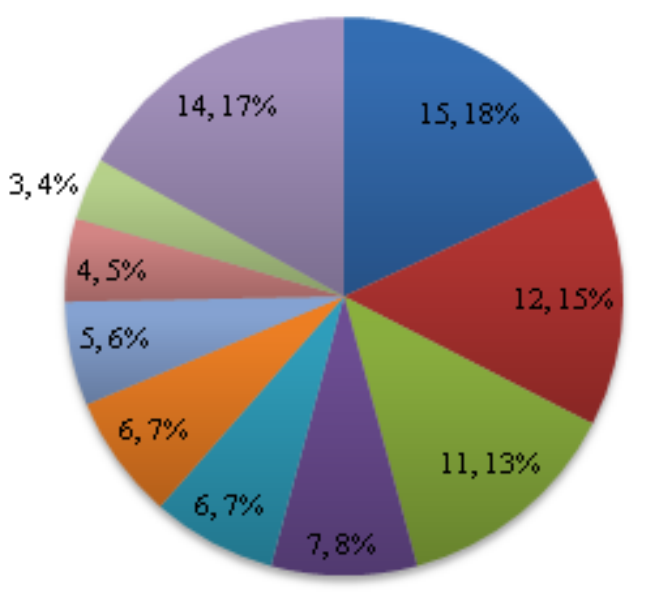

\begin{tabular}{|c|c|c|c|}
\hline E Sulphur & $\square$ Thuja occidentalis & - Calcarea carbonica & - Natrum muriaticum \\
\hline$=$ Nitric acid & = Pulsatilla nigricans & E Phosphorus & Lachesis muta \\
\hline Sepia succus & Miscellaneous & & \\
\hline
\end{tabular}

Figure 2: Medicines used in the study

Table 2: Changes in vitiligo outcome parameters 


\begin{tabular}{|c|c|c|c|c|}
\hline \multirow{2}{*}{ Outcome measures } & \multicolumn{3}{|c|}{ Median values (Inter Quartile Range) } & \multirow{2}{*}{$\mathrm{X}^{2} ; p$ value } \\
\hline & At baseline & After 3 months & After 6 months & \\
\hline VASI total & $0.8(0.5$ to 1.5$)$ & $0.8(0.5$ to 1.3$)$ & $0.7(0.3$ to 0.8$)$ & $11.7 ; 0.003^{*}$ \\
\hline \multicolumn{5}{|l|}{ VETF } \\
\hline 1. Staging & 1 (1 to 2$)$ & 1 (1 to 2 ) & 1 (0 to 1$)$ & $12.4 ; 0.002^{*}$ \\
\hline 2. Spread & $1(0$ to 1$)$ & $0(0$ to 1$)$ & $-1(-1$ to 0$)$ & $22.2 ; 0.0001^{*}$ \\
\hline \multicolumn{5}{|l|}{ DLQI } \\
\hline Total score & 21 (17 to 22$)$ & 17 (13 to 19$)$ & 13.6 (10 to 17 ) & $26.6 ; 0.0001^{*}$ \\
\hline $\begin{array}{l}\text { 1. Symptoms, } \\
\text { feelings }\end{array}$ & $5(4$ to 6$)$ & $4(4$ to 5$)$ & $3.6(3$ to 4$)$ & $17.7 ; 0.0001^{*}$ \\
\hline 2. Daily activities & $4(3$ to 5$)$ & $4(2$ to 4$)$ & $3(2$ to 4$)$ & $14.3 ; 0.0001^{*}$ \\
\hline 3. Leisure & $4(4$ to 5$)$ & $4(3$ to 4$)$ & $3(2$ to 4$)$ & $18.8 ; 0.0001^{*}$ \\
\hline 4. Work, school & $2(2$ to 2$)$ & $2(1$ to 2$)$ & $1(1$ to 1.1$)$ & $13.4 ; 0.001^{*}$ \\
\hline $\begin{array}{ll}\text { 5. } & \text { Personal } \\
& \text { relationship }\end{array}$ & $4(2$ to 5$)$ & 3 (2 to 4$)$ & $2.6(2$ to 3$)$ & $16.6 ; 0.0001^{*}$ \\
\hline 6. Treatment & 1.5 (1 to 2$)$ & $1(0$ to 1$)$ & $0(0$ to 1$)$ & $21.3 ; 0.0001^{*}$ \\
\hline
\end{tabular}

Friedman's test; * $p$ value $<0.05$ two-tailed considered as statistically significant.

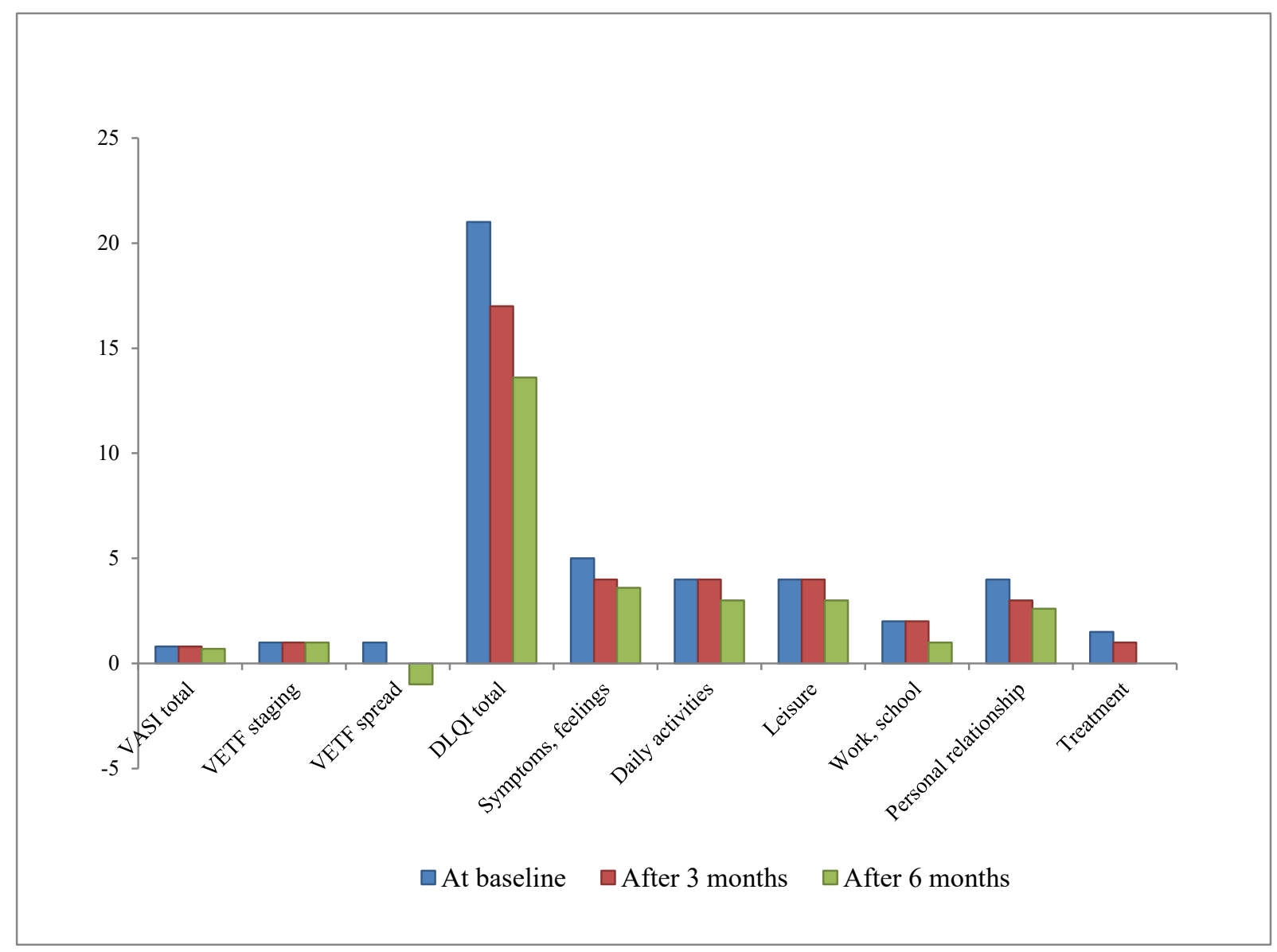

Figure 3: Changes of vitiligo median outcome measures over time with homeopathic treatment

Total VASI score improved significantly ( $p=0.003$ two-tailed, Friedman's test) from $0.8(0.5,1.5)$ at baseline to $0.8(0.5,1.3)$ after 3 months and to $0.7(0.3,0.8)$ after 6 months. Similar significant improvement $(p=0.002)$ 
was noticed in VETF staging, when the scores at the three time-points were compared. Significant reduction $(p=0.0001)$ of vitiligo lesions was also observed from $1(0,1)$ to $0(0,1)$ to $-1(-1,0)$ at baseline, after 3 months and 6 months respectively. Similar changes were obtained in the DLQI questionnaire. The total DLQI score decreased from $21(17,22)$ to $17(13,19)$ and $13.6(10,17), p=0.0001$. The 6 components of DLQI, namely symptoms and feelings, daily activities, leisure, work and school, personal relationship, and treatment also improved significantly $(p<0.05)$. (Table 2 , Figure 3 )

\section{Discussion}

This prospective observational study aimed to provide an overview of homeopathic care and outcomes in 30 patients with vitiligo. During the period of observation, assessment of the outcome measures consistently showed substantial improvement.

The study by Prasad RVR et al [30] from 1987 to 2003 involved 282 vitiligo patients and reported various degrees of improvement in 182 of them after homeopathic treatment. The medicines mostly used were Arsenicum sulphuratum flavum, Arsenicum album, Nitricum acidum; and Syphilinum as intercurrent. The study by Shraddhyamayananda S et al [31] from 2006 to 2010 included 200 patients, and found improvement in 190. Those findings were substantiated by pre- and post-test biopsy of the patches. the most frequently used medicines were Calc, Lycopodium clavatum, Lachesis muta, Mezereum, Natrum muriaticum, Sepia officinalis, Ars-s-f, and Ars. The Government of NCT of New Delhi, India launched two clinical research projects on vitiligo in Nehru Homoeopathic Medical College and Hospital and B R Sur Homoeopathic Medical College, Hospital and Research Centre in 2001 and 2003, respectively [32,33]. The first study recruited 199 participants, among whom, 118 reported various degrees of improvement. Nat-m, Nux vomica, Sulph, Puls, Lyc, Phosphorus, Calc, Calcarea phosphorica were the main medicines used, along with Tuberculinum bovinum, Syph, and Carcinosinum as intercurrent, and Mangifera indica, Mica, Ars-s-f, and Psoralea corylifolea as specifics. The latter one was was used 64 patients, 44 of whom exhibited positive results. Ars, Ars-s-f, Argentum nitricum, Calc, Ignatia amara, Lyc, and Kalium carbonicum were the mostly used remedies, along with Carc, Tub, and Syph as intercurrent. Frequent prescriptions of Sulph and Calc in our study corroborates the findings of earlier studies, however, Ars was indicated infrequently and Ars-s-f in no case. It should be observed that the sample size was too small to infer sound conclusions on the medicines more suitable to treat vitiligo.

Almost equal incidence of vitiligo was found among the males and females in our study, which agrees with earlier findings [34-36]. Occurrence of vitiligo mostly in individuals 21-40 years old also corroborates previous study results [37]. Prevalence of positive family history was comparatively lower in our study than earlier ones [35,38,39]. History of injury as a precipitating factor of vitiligo was also found, corroborating with previous studies [37].

The methodological strengths of our study including consecutive patient enrolment, use of standardized outcome instruments, and prescription by a registered postgraduate physician practicing 'classical' or individualized homeopathy reflect a reasonably representative sample of contemporary homeopathic practice. Therefore, it should be stressed that our results represent that variety of homeopathic approach only. In contrast to randomized trials, our study described patients from everyday practice with multiple morbidities and varying lifestyles. This ensures a high degree of external validity that allows extrapolation to usual medical care. In future research, assessments and diagnoses by dermatologists would be valuable to certify the diagnosis through more standardized and objective criteria. Our study evaluated the complete package of homoeopathic treatment, including context and placebo effects, and possible additional treatments in a usual care situation. The extent to which the observed effects are due to the applied homoeopathic remedies cannot be determined because no suitable methodology was used. Therefore, our study must not be interpreted as supportive of conclusions regarding the efficacy of homeopathic remedies in the treatment of vitiligo, but the total effect of consulting a homoeopath. We were also unable to find other evaluations of high-potency 
homeopathy for vitiligo, so the question on the efficacy of any single remedy remains unanswered. The costeffectiveness of homoeopathic treatment also remained uninvestigated.

\section{Conclusion}

Patients with vitiligo treated with 'classical' homoeopathy showed marked health and QoL improvements. However, the true extent of placebo or context effects in homoeopathic treatment was not been investigated, and detangling these factors will be a challenging, but promising task for future research.

\section{Acknowledgements}

The authors would like to acknowledge Prof. Dr. Amitava Biswas, Principal, Mahesh Bhattacharyya Homoeopathic Medical College and Hospital for permitting us to conduct the study in his institution. We are also grateful to the technical staffs and the patients for their participation and contribution to make this study successful.

\section{References}

[1] Whitton M, Pinart M, Batchelor J, et al. Interventions for vitiligo. Cochrane Database Syst Rev 2010;1:CD003263.

[2] Howitz J, Brodthagen H, Schwartz M, Thomsen K. Prevalence of vitiligo. Epidemiological survey on the Isle of Bornholm, Denmark. Arch Dermatol 1977;113:47-52.

[3] Boisseau-GarsaudAM, Garsaud P, Cales-Quist D, et al. Epidemiology of vitiligo in the French West Indies (Isle of Martinique). Int J Dermatol 2000;39:18-20.

[4] Whitton ME, Ashcroft DM, Barrett CW, Gonzalez U. Interventions for vitiligo [Systematic Review]. Cochrane Database of Systematic Reviews 2007;3.

[5] Sehgal VN, Srivastava G. Vitiligo: compendium of clinico-epidemilogical features. Indian Journal of Dermatology, Venerology and Leprology 2007,73(3):149-56.

[6] Parsad D, Pandhi R, Juneja A. Effectiveness of oral Ginkgo biloba in treating limited, slowly spreading vitiligo. Clinical \& Experimental Dermatology 2003,28(3):285-7.

[7] Halder RMMD, Nootheti PKMD. Ethnic skin disorders overview. [Miscellaneous]. Journal of the American Academy of Dermatology 2003;48((6 Part 2) Supplement):S143-S148.

[8] Behl PN, Bhatia RK. 400 cases of vitiligo - A clinico-therapeutic analysis. Indian Journal of Dermatology 1971;17:51-3.

[9] Mehta HR, Shah KC, Theodore C. Epidemiological study of vitiligo in Surat area, South Gujarat. Indian Journal of Medical Research 1973;61:145-54.

[10 Barona M, Arrunategui A, Falabella R, Alzate A. An epidemiologic case control study in a population with vitiligo. Journal of the American Academy of Dermatology 1995;33(4):621-5.

[11] Ongenae K, Beelaert L, Van Geel N, Naeyaert JM. Psychosocial effects of vitiligo. Journal of the European Academy of Dermatology \& Venereology 2005;20:1-8. 
[12] Porter J, Beuf AH, Nordlund JJ, Lerner AB. The effect of vitiligo on sexual relationships. Journal of the American Academy of Dermatology 1990;22(1 Pt. 1):221-2.

[13] Porter J, Beuf AH, Nordlund JJ, AB L. Response to cosmetic disfigurement: Patients with vitiligo. Cutis 1987;39(6):493-4.

[14] Porter J, Beuf A, Nordlund JJ, et al. Personal responses of patients to vitiligo: the importance of the patient-physician interaction. Arch Dermatol 1978;114:1384-5.

[15] Porter J, Beuf AH, Nordlund JJ, et al. Psychological reaction to chronic skin disorders: a study of patients with vitiligo. Gen Hosp Psychiatry 1979;1:73-7.

[16] Papadopoulos L, Bor R, Legg C. Coping with the disfiguring effects of vitiligo: a preliminary investigation into the effects of cognitive behavioural therapy. Br J Med Psychol 1999;72:385-96.

[17] Lerner AB, Nordlund JJ. Vitiligo. What is it? Is it important? JAMA 1978;239:1183-7.

[18] Grimes PEMD. New Insights and New Therapies in Vitiligo.[Miscellaneous Article]. JAMA 2005;293(6):730-5.

[19] Forschner T, Buchholtz S, Stockfleth E. Current state of vitiligo therapy-evidence-based analysis of the literature. [Review] [30 refs]. Journal der DeutschenDermatologischenGesellschaft 2007;5(6):467-75.

[20] Chu CY, Liu YL, Chiu HC, Jee SH. Dopamine-induced apoptosis in human melanocytes involves generation of reactive oxygen species. British Journal of Dermatology 2006;154(6):1071-9.

[21] Park ES, Kim SY, Na JI, Ryu HS, Youn SW, Kim DS, Yun HY, Park KC. Glutathione prevented dopamine-induced apoptosis of melanocytes and its signaling. Journal of Dermatological Science 2007;47(2):141-9.

[22] Eleftheriadou V, Whitton ME, Gawkrodger DJ, Batchelor J, Corne J, Lamb B, et al. Future research into the treatment of vitiligo: where should our priorities lie? Results of the vitiligo priority setting partnership. $\mathrm{Br}$ J Dermatol 2011;164:530-6.

[23] Radtke MA, Schafer I, Gajur AI, et al. Clinical features and treatment outcomes of vitiligo from the patients' perspective: results of a national survey in Germany. Dermatology 2010; 220:194-200.

[24] Szczurko O, Boon H. A systematic review of natural health product treatment for vitiligo. BMC Dermatology 2008;8(2).

[25] Panin G, Strumia R, Ursini F. Topical [alpha]-Tocopherol Acetate in the Bulk Phase: Eight Years of Experience in Skin Treatment. Annals of the New York Academy of Sciences 2004;1031:443-7.

[26] Ichiro K, Aki MA, Kumiko E, Sang JB. Vitamin D3 and solar irradiation in the treatment of vitiligo vulgaris. Journal of the European Academy of Dermatology \& Venereology Supplement 2002;16(Supplement 1):341.

[27] Shigetoshi S. Treatment of vitiligo with Vitamin D3 (tacalcitol). Journal of the European Academy of Dermatology \& Venereology Supplement 2002;16(Supplement 1):275.

[28] Siddiqui AH, Stolk LML, Bhaggoe R, Hu R, Schutgens RBH, Westerhof W. L-Phenylalanine and UVA irradiation in the treatment of vitiligo. Dermatology 1994;188(3):215-8. 
[29] Cormane RH, Siddiqui AH, Westerhof W, Schutgens RB. Phenylalanine and UVA light for the treatment of vitiligo. Archives of Dermatological Research, 1985;277(2):126-30.

[30] Prasad RVR, Raveender C, Lakshmi B, Singh K, Vichitra AK, Oberoi P, Mittal R. Clinical evaluation of pre-defined homoeopathic medicines in vitiligo. Clinical Research Studies 2009, Series II, pp. 85-92; Central Council for Research in Homoeopathy, New Delhi, Govt. of India.

[31] Shraddhyamayananda S, Dasgupta S, Basu SK, Swarnakar G. Significant remission of vitiligo by ultradiluted alternative medicines. Asian J Pharm Clin Res 2012;5(2):33-5.

[32] Khanna VK. Clinical approach to vitiligo at Nehru Homoeopathic Medical College and Hospital, New Delhi. The Homoeopathic Prestige 1992;8(7 and 8):263-72.

[33] Mehan N. Clinical Research in Vitiligo. Available at http://www.delhi.gov.in/wps/wcm /connect/ DoIT/delhi+govt/delhi+home, accessed May 28, 2013; CDirectorate of ISM \& Homoeopathy, Homoeopathic Wing, Govt. of NCT of Delhi, India.

[34] Das SK, Majumder PP, Chakraborty R, Majumdar TK, Halder B. Studies on vitiligo: epidemiological profile in Calcutta, India. Genet Epidemiol, 1985;2:71-8.

[35] Dutta AK, Mondal SB. A clinical study of vitiligo. Indian J Dermatol, 1969;15:103-5.

[36] Marks R. Roxburgh's common skin diseases. Hodder Arnold Publishing, 117 th edition, 2003;pp 1-11, 2958.

[37] Freedberg IM, Arthur Z, Klauss W, Austen KF, Lowell AG, Stephen K. Fitzpatrick's dermatology in generalmedicine; $6^{\text {th }}$ edition, New Delhi. McGraw-Hill Professional, 2003.

[38] Bhutani LK, Khanna N. Bhutani's colour atlas of dermatology, $5^{\text {th }}$ edition; New Delhi. Mehta Publishers, 2006; p147.

[39] Koranne RV, Sehgal VN, Sachdeva KG. Clinical profile of vitiligo in North India. Indian J DermatolVenereolLeprol, 1986;52:81-2.

\section{Tratamento homeopático do vitiligo: estudo piloto observacional aberto}

\section{RESUMO}

Introdução: Vitiligo é uma desordem de hipopigmentação de ocorrência comum, com impacto psicológico significativo. Foi avaliado o tratamento homeopático de indivíduos com vitiligo no ambulatório de um hospital em Bengala Ocidental, Índia. Métodos: Trinta participantes (idade mediana 27 anos, sendo $57 \%$ do gênero feminino) foram recrutados para o presente estudo piloto prospectivo aberto e tratados com medicamentos homeopáticos individualizados por 6 meses. A eficácia do tratamento foi avaliada aos 3 e 6 meses mediante Vitiligo Area Scoring Index (VASI) score, Vitiligo European Task Force (VETF), e Dermatological Life Quality Index (DLQI), que são medidas validadas de desfecho correspondendo à área, intensidade e disseminação da depigmentação causada por vitiligo, assim como a qualidade de vida (QV). Resultados: Um total de 27 participantes completou o estudo, sendo que 3 abandonaram. Depois de 6 meses de tratamento, a mediana do escore total do VASI apresentou melhora significativa de 0,1 unidade $(p=0,003)$ passando de $0,8(0,5,1,5)$ para $0,7(0,3,0,8)$, numa escala de 0 (sem depigmentação) a 100 (depigmentação completa). De modo similar, a mediana do escore VETF de disseminação 
melhorou em 2 unidades $(p=0,0001)$ de $1(0,1)$ a $-1(-1,0)$, e o escore de estadiamento variou de 1 $(1,2)$ para $1(0,1), p=0,002$. O escore total mediano de DLQI diminuiu de $21(17,22)$ a $13,6(10$, $17)$, com uma variação de 7,4 ( $p=0,0001)$; variação também foi constatada nos componentes de DLQI. Conclusões: O tratamento homeopático individualizado se associou com melhora significativa nos escores de VASI, VETF e DLQI. A parte dos efeitos possivelmente devida a efeito placebo precisa ser determinada em futuros estudos clínicos randomizados e duplo cego, após a realização de estudos de factibilidade.

Palavras-chave: homeopatia, vitiligo

\section{Tratamiento homeopático del vitíligo: estudio piloto observacional abierto}

\section{RESUMEN}

Introducción: Vitiligo es un trastorno de hipopigmentación común, co impacto psicológico significativo. Fue evaluado el tratamiento homeopático de individuos con vitíligo en el consutlorio externo de un hospital en Bengala Occidental, India. Métodos: Treinta participantes (mediana de edad 27 años, siendo $57 \%$ del sexo femenino) fueron reclutados en este presente estudio piloto prospectivo abierto e tratados con medicamentos homeopáticos individualizados por 6 meses. La eficacia del tratamiento fue evaluada a los 3 y 6 meses mediante Vitiligo Area Scoring Index (VASI) score, Vitiligo European Task Force (VETF), y Dermatological Life Quality Index (DLQI), que son medidas validadas de resultados correspondiendo al área, intensidad y diseminación de la despigmentación causada por vitíligo, e igualmente la calidad de vida (QV). Resultados: Un total de 27 participantes terminó el estudio, siendo que 3 abandonaron. Con 6 meses de tratamiento, la mediana del escore total del VASI presentó mejoría significativa de 0,1 unidad $(p=0,003)$ pasando de $0,8(0,5,1,5)$ a $0,7(0,3,0,8)$, en una escala de 0 (sin despigmentación) a 100 (despigmentación completa). De modo similar, la mediana del escore VETF de diseminación mejoró en 2 unidades $(p=0,0001)$ de $1(0,1)$ a $-1(-1,0)$, y el escore de estadificación varió de $1(1,2)$ a $1(0,1), p=0,002$. La mediana del escore total de DLQI disminuyó de $21(17,22)$ a 13,6 $(10,17)$, con variación de 7,4 $(p=0,0001)$; variación también fue constatada en los componentes del DLQI. Conclusiones: El tratamiento homeopático individualizado se asoció con mejoría significativa de los escores en VASI, VETF y DLQI. La parte de los efectos posiblemente debida a efecto placebo debe ser determinada e futuros estudios clínicos aleatorizados e doble ciego, después de la realización de estudios de factibilidad.

Palabras clave: homeopatía, vitiligo

\section{(cc) EY-NC-ND Licensed to GIRI}

Support: authors declare that this study received no funding Conflict of interest: authors declare there is no conflict of interest

Received: August 07th 2013; Revised: November $3^{\text {rd }} 2013$; Published: December $18^{\text {th }} 2013$.

Correspondence author: Subhasish Ganguly, drsubhasishganguly@hotmail.com

How to cite this article: Ganguly S, Saha S, Koley M, Mondal R. Homoeopathic treatment of vitiligo: an open observational pilot study. Int J High Dilution Res [online]. 2013 [cited YYYY Month dd]; 12(45):168-177. Available from: http://www.feg.unesp.br/ ojs/index.php/ijhdr/article/view/638/683 